\title{
Rainbow Nation's Ubuntu: Discovering Distinctness as a Spectrum Through South African Literature
}

Apartheid created more than physical distances between color groups; South Africa is made up of people with often separated minds. Leaders of the democratic government draw from and modify the ancient African tribal value called ubuntu as the philosophic basis for their cultural strategy of unification. From this idea of ubuntu, new visual concepts to represent the country have emerged, such as the Rainbow Nation of God, which draws on the Biblical promise of peace and the visual lesson of distinct but inseparable colors as a powerful rhetorical tool for unity. While colonization and the new threat of globalization both typically declare themselves good proportionate to the evilness of the other, such division is precisely what ubuntu challenges. To be unified, all are accountable to each other. But white writers in South Africa, with their mostly European existence, have struggled to concede any such responsibility or remorse for their part in what went wrong in their country's history.

Sandra Chait has pointed out that much of white writing in South Africa has, in its search to understand the country's past, inadvertently blamed essential human nature for the wrongs of apartheid. She highlights literary myths such as the Apocalypse that validate violence and brutality simply because the cruel events entailed in such myths are understood to be predetermined. In many texts produced by whites, humans "simply act out their 'natural' destinies, unable to alter the "natural' order of their predetermined roles in the universe" ("Mythology, Magic Realism" 2 on internet). All savagery is ascribed to "that ultimate avenger, the betrayed God who seeks to wreak His revenge" in order to justify white brutality in Africa as an instinctive response to violence of the other ( 5 on internet). This ideology, she concludes, is an alibi to excuse whites from responsibility for the past and inevitably postpone reconciliation between white and black South Africans.

I chose three novels to study_Antjie Krog's Country of My Skull, Nadine Gordimer's Burger's Daughter, and J.M. Coetzee's Disgrace—precisely because I believe they avoid such alibis. In them, ultimately, nothing justifies the violence man is capable of inflicting on others, but is explainable only through gross violations of inherent human interrelations. Inhumanity is inexcusable in a community existence of interdependence that their respective plots gesture 
towards. As the protagonists of these novels come to understand this, they assume personal responsibility themselves for what has gone wrong and make some kind of significant gesture of personal commitment to the present and future. In this transition to a new standard of humanity different from that which had long underscored arguably every interaction in South Africa's apartheid history, the protagonists of these novels, and perhaps more importantly-their authors - separate themselves from Western paradigms and by virtue of how they learn to consider others are reinvented, creating a space for themselves to no longer be solely European, but to become uniquely South African.

Antjie Krog's Country of My Skull covers the proceedings of the Truth and Reconciliation Commission, but its most significant comments happen in the margins and gaps of the actual dialogue that happens before public eyes and ears. The book maps the personal journey of its author from the racial standard of humanity that is wounded and dying in the new South Africa to a "new" African method of identification through others. For the author of the novel as well as for those who testified before the TRC, human dignity is restored through the act of storytelling. Although she realizes that in the act of reconciliation through stories "what is important is not so much what is told... but rather that telling occurs,"(Sanders 18) Krog is nevertheless noticeably uncomfortable in the telling of her story. As an author, she speaks in many different styles in almost desperate attempts to find the best way to relay the grief and awkwardness she feels as a result of not belonging to the national narrative of suffering she is exposed to. As Mark Sanders says, the book is "written at the edges of reportage, memoir, and metafiction" (16). The resultant narrative complexity gives the book a thickness that defies simplistic readings. Interpretation is complicated as the book vacillates between fact and fiction (history and literature) through its anxious shifts in authorial style and between an awareness of the inadequacy of language to express and an irresistible drive to speak through it.

Caught in this linguistic no-man's-land, Krog seeks a side to take. But to do this means either confessing or denying complicity in apartheid; and to do one or the other is equally painful for her. She will not retreat to the culture that has brought her up because of how openly it has been exposed by the personal accounts related before the commission: "Because of these narratives, people can no longer indulge in their separate dynasties of denial" (113). And she cannot yet hope to be embraced by the native Africans precisely for belonging to the camp of oppressors. So much of her voice is spoken in an anguished tone that results from being pulled to two poles that are both never real possibilities for her, at least at present; she does not belong in either place. In the Western 
racially-based paradigms, she cannot belong as long as she pleads ignorance and evades responsibility. She refuses the privileged side of the oppressors outright in her novel, yet feels unworthy to be welcomed by the oppressed.

It at first seems evasive and irresponsible for the author to refuse to stand by a single method of representation. But the book's narrative style itself is actually an effective rendering of what the author has learned from the commission. Her aesthetic technique thus couples the principal message of her novel: reconciliation is found through the magnification of many layers. This comes as a result of how contradicting testimonies were treated in the TRC. For this reason the victims' testimonies were never scrutinized, but were "decidedly nonjudicial, involving no cross-examination of testimony, and were intended to provide a safe space for some victims of human rights violations to have their accounts of the past made part of the official record" (Graham 1).

But again, the reasons were manifold for creating a story-hearing commission. The goal was even more than the worthy goal of helping the "marginalized voice[s]" speak to "the public ear" (Krog qtd. in Cook 8); it was to establish a standard that represents itself through a complex model that shuns simplification and renders reductions useless. Krog discovers this model as the underpinnings of the commission's work in an interview with Bishop Desmond Tutu, the commission's chair and its ideological role-model. She asks him: "Weren't you irritated that you had to listen to four versions of South Africa's past?" But he provides an answer she hadn't anticipated: "Four versions...four...exist of the life of Christ. Which one would you have liked to chuck out?" Apparent in Bishop Tutu's response is the belief that contradictions inherent in combining different histories matter less than the supplementary information they provide. She realizes, in a manner she describes as "instinctive," that this complex method of representation will prevail over simplistic histories of the country and lead South Africa to its future: "if you cut yourself off from the process, you will wake up in a foreign country - a country that you don't know and that you will never understand" (172).

By the close of her novel, entry into the South African community is, as yet, not a possibility, according to some scholars. To some, the title-Country of My Skull-demonstrates how the connection of author and country manifests itself as merely wishful thinking: "internally created...perhaps of the imagination or of memory" (685). Meira Cook agrees that true reconciliation remains unachieved for the author, and points to the narrative's ending as a symbol of her continuing passage into a new standard of humanity. On a boat with other commissioners returning to Cape Town from Robben Island, "she ends her narrative 
in limbo, between land masses, dissenting opinions, and the dilemmas of the divided heart" (9). Though she has not yet arrived, I argue that she is closer to her destination than to her origin. The poetry she closes the novel with bears this out powerfully: "the retinal learns to expand / daily because by a thousand stories / I was scorched / a new skin” (Krog 364). With her new body—an expanded eye and a new skin-Krog already feels reinvented and rejuvenated.

Though her exposure to the stories told in the TRC was unnerving and unsettling, it was necessary for revitalization. Though the listener may struggle momentarily to free herself from the burden newly shared with her, the tellers get therapy and catharsis by public acknowledgment of their pain (Sanders 21) and the endeavor pushes them all towards equilibrium. We may say that with the weight-shifting of guilt, one person is raised up while the other is brought down: the resulting reconciliation is the point of the whole endeavor. And division is discovered as the eternal detriment: "The primary cancer will always be and has always been apartheid" (324).

The question that Gordimer is engaged with most noticeably in her novel Burger's Daughter is about the practicality of the rhetoric of unity in South Africa: can whites ever be accepted by and allied with blacks? If so, what exactly is the price to be paid for that acceptance and alliance?

During the 1970s, when the novel was written, social consciousness for whites easily seemed a thankless and fruitless endeavor. While the inhumanity of apartheid was apparent outright, the role whites should take against it was becoming more and more vague. Most of the gestures that whites made "in behalf” of blacks were rejected by blacks for being patronizing and inadequate. The authenticity and ability of white liberals was already seriously doubted by black leaders. For leaders like Steve Biko, help could never come from "a group with lots at stake in the status quo" (Biko 11). He rejected the idea of whites doing everything for blacks, marking it as old as the white presence itself in South Africa. As the father of Black Consciousness in South Africa, he called white subversive activity artificial because he felt it was inevitably "a response to conscious manoeuvre rather than to the dictates of the inner soul” (21). Denouncing the overwhelming presence of whites in the front lines of political activities for a nonracial South Africa, black consciousness accused them of claiming "a monopoly on intelligence and moral judgment" (22-3). Their very presence in South Africa was threatened as it became attached to apartheid itself.

During a period when white motives were said to be born out of guilt rather than of genuine concern, a white person was easily left with hard options regarding how to resolve the complex racial struggle in his or her country. The 
conversation Rosa observes at Marisa's home in the township addresses precisely this issue. Rosa is sensitive to the young students' claim that white participation is a pathetic outgrowth of the "liberal myth of reconciliation" (Clingman qtd. in Folks 4 internet). Dhladhla identifies white liberal agendas as simple "race exploitation with the collaboration of blacks themselves. That is why we don't work with whites. All collaboration with whites has ended in exploitation of blacks" (BD 159). Their reluctance to cooperate with whites is the broken faith of their ancestors who were "tricked" to lose themselves "in some kind of colourless...shapeless...'humanity' (164).

But for Rosa, a colorless community with blacks has been a formative part of her identity. In her house, where "blackness was a sensuous-redemptive means of perception" (135), she always took for granted the ability of whites and blacks to connect and understand each other. Rosa comes to doubt the capacity for people to escape racially-bound paradigms, until it reaches its height in the decisive conversation with her formerly adopted brother Baasie, who mocks her with the question: "Unless you want to think that being black is your right?” (321).

Rosa's "coming of age" is contingent on an analysis of her famous family's "colourless" morality from within another context completely. She leaves to Europe to "defect from" her father, desperately wanting to believe that, as Katya decides, "'there's a whole world' outside what he lived for, what life with him would have been" (264). From France, she is able to reflect on her life until now and decide what her role will be in the future. There she is dazzled momentarily by the private, hedonistic lives Madame Bagnelli and her friends live in France.

It is the question of suffering and responsibility that determine Rosa's presence in South Africa; the cause for her leaving and returning is the same. The cruel beating of the donkey outside a township drives her to France, while both the pathetic way Madame Bagnelli and her friends try to postpone inevitable aging and death and her bitter quarrel with her former adopted brother drive her home. She comes to understand the difference between universal suffering, which cannot be avoided (like the dead man on a park bench that stunned her as a young girl, like the aging women in denial) and political suffering, which one can grapple with and possibly change. This realization marks the end of Rosa's passage into maturity: in life there is suffering, and one decides whether it will be with or against your core values. Finally Rosa realizes that "no one can defect. I don't know the ideology: It's about suffering. How to end suffering. And it ends in suffering. Yes, it's strange to live in a country where there are still 
heroes. Like anyone else, I do what I can” (332). The novel closes with Rosa in prison, resigned to "do all she can" to help end suffering in her country.

In Coetzee's Disgrace, Professor David Lurie is a communications professor who, ironically enough, struggles to communicate sincerely with the people around him. After a sexual affair with a student turns sour, he finds himself amid a scandal at his university and is summoned to an inquiry before his colleagues. At the hearing, he refuses to provide defense for himself and pleads guilty. When some of his colleagues grow incensed at his arrogance, they demand an apology. Once he offers it, his sincerity is questioned and he is at a loss to understand what sincerity matters in legal proceedings such as his: "Then what do you advise me to do? Remove what [you call] the subtle mockery from my tone? Shed tears of contrition? What will be enough to save me?" (52). His colleague Dr. Swarts replies that Lurie should understand that "certain sacrifices" must be made for "the good of the whole" (52), and any breeches must be addressed with "a spirit of repentance" (58). Lurie, outraged and somewhat confused replies, shaking his head: "I have said the words for you, now you want more, you want me to demonstrate their sincerity. That is preposterous. That is beyond the scope of the law. I have had enough. Let us go back to playing it by the book" (55). During an intermission in the hearing, he wonders, "Confessions, apologies: why this thirst for abasement?" (56).

David Lurie's hearing has particular parallels with the perpetrators' trials in the TRC. For many of those who were called before the commission for violating human rights, it was peculiar and irrational to ask for more than cold explanations and heartless confessions. They believed, as David Lurie did, that a secular plea of guilty should suffice: "Repentance is neither here nor there. Repentance belongs to another world, to another universe of discourse" (58). Though his colleague tries to distinguish what they were asking of him from repentance, it is precisely that change of character that they, as well as the commission called to set South Africa on strong moral feet, wanted: "to acknowledge your fault in a public manner and take steps to remedy it" (58).

David Lurie comes to understand the necessity of a lived apology by the end of the novel. After leaving the university where he teaches, he goes to live with his daughter Lucy on a rural farm in the Eastern Cape. He begins work at Bev Shaw's animal clinic as a volunteer only after he makes clear that his service will not be "reparation for past misdeeds. All right, I'll do it," he says, "but only as long as I don't have to become a better person. I am not prepared to be reformed" (77). His time with his daughter again exposes him to a situation in which people are acting according to a morality that is foreign to him. When 
his daughter refuses to accuse her rapers to the authorities, he disapproves of her reasoning: "Do you think that what happened here was an exam: if you come through, you get a diploma and safe conduct into the future, or a sign to paint of the door-lintel that will make the plague pass you by...Is it some form of private salvation you are trying to work out? Do you hope you can expiate the crimes of the past by suffering in the present?" (112).

Indeed Lucy's decision to endure the unendurable in silence is perplexing. The complexity of that decision is unfathomable without some understanding of the standard of humanity that is common among Lucy and her neighbors. In her mind, the future she envisions for herself and her country depends on her refusal to live different in any way from the rest of the community, but more so, on her willingness to live her own apology for the past. While her decision is perhaps somewhat too self-sacrificial, Lucy and her morality are nevertheless rather contagious for her father. He takes advantage of an invitation to visit the family of the young student he had an affair with, and there apologizes and asks forgiveness from her parents for the pain he has caused them. The novel closes on his best personal sacrifice; he hands over a dog he admits he has grown to love to Bev Shaw to be put to sleep even though he could have waited another week. "Are you giving him up?" Bev asks him. "Yes, I am giving him up" (220). This notion of sacrifice and responsibility changes David Lurie despite himself and he thus not only learns but begins to live in his way the principles necessary to improving the strained human relationships in South Africa.

To conclude, these three novels gesture towards a necessary transition to social responsibility in South Africa by avoiding any self-consoling alibis and advocating individual commitment to the social and political situations in the country. The individual is denied his or her rights to live a private, indulgent life at the expense of others; any methods of representation and interpretation based on binaries and division transform into community-based paradigms. Inasmuch as Krog, Gordimer, and Coetzee promote such ubuntu-based views of humanity, being interdependence and mutual accountability, they move to overcome the individualistic ideologies inherent in the European tradition they are often associated with, and become uniquely South African. 